\title{
A RETROSPECTIVE ANALYSIS OF THE INTERRELATED DEVELOPMENT OF SCIENCE AND HIGHER EDUCATION IN THE WORLD
}

\author{
Andrey Leonidovich Pozdnyakov*, Ekaterina Viktorovna Pozdnyakova, Anna Vladimirovna Ozerova \\ Faculty of Building and Architecture, Southwest State University, Kursk, Russian Federation
}

The article discusses the process of forming scientific and educational centers in a historical context. Science and education have been developed in interconnection since ancient times. Changes in one area have always entailed changes in another. All these transformations were naturally reflected in the architectural and planning appearance of educational objects. Initially, universities did not have their own buildings, and classes were held in rented premises. At the same time, students and teachers tried to settle near the classrooms. Over time, this led to the formation of colleges, university complexes, campuses, and later entire university cities. When considering examples of university complexes in various cities and countries, the main fundamental components of modern scientific and educational centers were highlighted. Based on this, it was concluded that at present the university is a space of education, science and communications, the joint work of researchers, specialists and students.

Key words: education, scientific and educational centers, architecture

\section{INTRODUCTION}

In a world where science and technology are changing so rapidly, the inevitability of profound changes in education seems inevitable. The emergence of new educational technologies, the expansion of the role of scientific research in the higher education system suggest that there are already visible changes in the educational process.

One of the phenomena on a global scale, without the influence of which today there is no sphere of public life, is the process of globalization. This process is particularly important in the context of the analysis of the problems of higher education and, in particular, one of the main issues is the spatial organization of educational facilities. Speaking about globalization in the field of education, there are three stages.

The first stage is characterized by the emergence of world religions at the beginning of a new era of chronology. The emergence of world religions is associated with the search for universal values, the possibility of leaving the systems of value orientation beyond national borders.

The second stage is due to the emergence of the first universities and refers to the beginning of the second Millennium. The establishment of universities helped to overcome the narrow limits of national-traditional, professional borders and to use more universal disciplinary practices.

The third stage is the beginning of the third Millennium, when there are new information and communication systems with computer technologies that allow interactive communication in synchronous mode.

To understand the functional structure and planning organization of the modern scientific and educational cen- ter, it is necessary to consider the historical aspects of the formation of the interrelated development of science and higher education [1].

\section{THE OBJECTS OF SCIENCE AND EDUCATION OF ANTIQUITY AND THE RENAISSANCE}

In ancient times science was a mixture of philosophy, formal and natural Sciences and was just beginning to create its own tools of knowledge of the objective world. The links between science and production were not obvious and were spontaneous - the creation of new technologies occurred empirically. At the same time, fairly strong ties have already been established in the field of training personnel: as a rule, a major scientist (thinker) acted as a teacher and head of a scientific school. It is no coincidence that the Plato Academy and Likey Aristotle are called the universities of the ancient world (scientific centers were simultaneously educational centers).

The era of Plato and Aristotle after two millennia gave way to the Renaissance. It brought a revival in the economy, a general upsurge of culture and, at the same time, a new wave of the development of science: in the XVI-XVII centuries in the countries of Western and Central Europe the first scientific and technological revolution took place. Scientific centers and scientific societies were created, old ones developed and new universities opened. The formation of modern science and the development of experimental research methods began.

The origin of the first university complexes is closely connected with the formation of medieval cities in Western Europe and was the result of the centuries-old genesis of the educational system. In the XII-XIII centuries the church and the state played the leading role in the formation of all spheres of medieval society. 
The expansion of the educational structure led to the emergence of the next stage - higher education. The term "university" (from the Latin Universitas- "community", "totality") appeared in Germany at the end of the XIV century and originally meant intelligent communities. Medieval universities were also called "universitasstudii" (academic corporation) or "universitasmagistrorumetscholarium" (corporation of masters and students) and had a number of distinguishing features:

- the presence of an internal hierarchy: a sequence of degrees of schoolchildren - bachelor - master doctor;

- consolidation of law (self-government, both at the level of the educational process, and at the level of administration and economic activity), the internal order at the university and its interaction with external institutions were established in a special code;

- universality-generality. Universities were interdisciplinary organizations with a common set of basic faculties (arts, jurisprudence, theology and medicine), and similar curricula, a common language (Latin), a common religion (Catholicism), and common diplomas [2].

The first university was opened in 1080 in Bologna (Italy). In other European cities, university centers arose much later. In 1209, the universities of Oxford and Cambridge (England) were opened. In 1215, the University of the Sorbonne was founded in Paris. The unification in 1218 of the schools of Salamanca (Spain) involved in the study of theology, law and medicine into a single educational institution led to the formation of a university in 1255 . Thus, by the beginning of the XIII century. The first five universities were formed in Europe, developing science in various fields and specialties of preparation: the University of Bologna was known for its successes in law, the University of Paris - in theology, and Salamanca was a center for research in the field of medicine.

In the XVI century 76 higher educational institutions functioned in Europe/ They differed from each other in size, specialization and teaching system. Initially, universities did not have their own buildings. Classes were held in rented premises, libraries, as well as in monasteries. Students and teachers tried to rent housing near the place of study or work, a locally concentrated student community influenced (not always positive) on the atmosphere of the urban environment.

Later, the first special educational buildings were built they were colleges (College in Bologna - CollegoSpagna, 1365; College of Balion, 1263; College of Metron, Oxford, 1264). The quadrangle, a closed square shape with a courtyard in the center, acted as the main volume. The college usually had a pronounced main axis and a hierarchy of internal spaces. The central place in the composition was occupied by the church (the importance of religion in the worldview was very great). Such an architectural and planning organization of space was called the monastery model. The planning structure of the university college was a closed, inward-oriented space, which largely reflected the reality of medieval society. A similar layout was used in the construction of medieval castles, monasteries (hence the continuity of the name), as well as earlier educational buildings. It should be noted that this planning scheme with some modifications is still used in the design of university buildings [3].

The expansion of the functions of educational buildings has led to the complexity of the initial structure due to the expansion and consolidation of complexes. Gradually, the university was filled with new functions, transforming into a complex with the allocation of residential, sports, educational and social zones. In this context, a close relationship with the city is an important feature of the archetype of European universities and an aspect of its urban structure. In an idealized world, it, like a castle or a monastery, is an isolated system in urban space - a local urban cell. Interaction with the city network is minimal. In practice, the university is a dynamic, non-linear structure, which is affected by the growth in the number of students, the need for research facilities, etc.

In some cases, the university becomes the predominant city-forming factor. The first university complexes carefully preserved not only traditions in education, but also traditions in relation to the architectural heritage. So, the planning structure of Oxford repeated the scheme of the ancient city. The two main streets intersect at right angles; at their intersection Modlen College with the Carfax tower is, which is the symbol of the city. The main streets are adjacent to squares and colleges. The space-planning decision of Oxford colleges is organized according to a single principle: the main entrance is accented by a large and deep arch from the street, in some cases the tower rises over it.

Formed by the XII century.urban planning and architectural planning principles for organizing a European campus become a prototype for many universities in Europe. So, in the XIII-XV centuries a number of large university complexes arose: the University of Montpellier, Padua, Neapolitan, Orleans, Toulouse, Leipzig universities.

Thus, at the first stages of its development science was incompatible with the existing system of higher education. Universities that were heavily influenced by the Church were not a place to experiment. Scientific societies and academies were established outside the University walls. The AccademiadeiLincei worked in the Palace of Duke Federico in Rome, the Royal Society of London - in the premises of Gresham College in London and the Paris Academy of Sciences - in the library of the king in Paris. All this had a negative impact on the development of science.

The academies, which needed an influx of young scientists, did not have the means to organize educational units, and university education remained scholastic and ignored the latest achievements of science:

As scientific knowledge was strengthened, the participation of scientists in teaching became more active and re- 
quired the concentration of science and education within a limited space. In the first third of the XVIII century. Scientific and educational centers began to appear - the Bologna Institute, Oxford University.

The change in the social system, the development of the institution of democracy, new scientific and technological achievements posed other tasks for the younger generation. Natural and technical sciences gradually replaced philosophy as a fundamental educational discipline. The idea of asceticism was gradually replaced by ideas of state greatness.

Medieval universities in the new conditions have become a conservative element that does not meet public demands. In terms of planning, a characteristic illustration of the conversion of universities was the preservation of a closed monastery model.

\section{FEATURES OF THE EVOLUTION OF UNIVERSITY SYSTEMS IN THE INDUSTRIAL AND POSTINDUSTRIAL PERIOD}

Manufactory and factory production, the industrial revolution, which began in Europe in the XVII century, change the Outlook of society: the ideal of an active thinking subject was replaced by actively producing, forming to the XIX century a new space-planning model of University complexes - "Palace of knowledge". New educational institutions are often located in the rebuilt palaces of the nobility or in buildings whose front view is not inferior to the elite buildings of classicism of the time.

Analyzing the space-planning model, we can distinguish a number of features: symmetry; hierarchy of spaces from the front to the service; centralized construction of hall spaces and corridor blocks. It was characterized by order, regularity, which was provided by the presence of axes of symmetry, hierarchy of spaces from the front to the service. A corridor with small classrooms led to larger classrooms, and the main hall led to a Central space - a hall or a library. Depending on the construction of the corridors were replaced by the Suite.

New educational institutions were located in the reconstructed palaces or in the buildings, which were not inferior to elite buildings and obeyed the classical principle of "beauty in structure".

The dynamic development of science in the mid-XIX early $\mathrm{XX}$ century led to a whole galaxy of great discoveries. The deepening of scientific knowledge, the increased number of laboratory studies required the transformation of the architectural and planning structure of scientific and educational facilities. Thus, the need to create special laboratories, which created special conditions for scientific experiments, became obvious.

The new model of university complexes, formed at the beginning of the $\mathrm{XX}$ century, is called the "Factory of Education". At this time, the theory and practice of architecture is changing. In the space-planning organization of a building, the specific technological or functional process, taking place in the building, becomes a factor forming the planning structure.

An important step towards the formation of a new model was the Bauhaus Higher School complex in Dessau (1926, architect V. Gropius). One can trace the ideological connection between the model of the University of W. Humboldt and education at the Bauhaus school. In the Bauhaus, great importance was given to free research in the process of cognition, but the nature of the research changed with the increase in practical studies and the further material implementation of projects. Workshops become an important element of the educational complex. Complexes of universities of the $X X$ century are a vivid example of the separation of design objects into unique and adapted for mass construction. The latter are characterized by the use of prefabricated unified designs.

The post-war period was characterized by a sharp increase in laboratories around the world. Many famous architects explored this topic in their work. In particular, Luis Kahn worked on a laboratory project at the University of Pennsylvania (Philadelphia, USA, 1957-1961), Philip Johnson designed a nuclear reactor in Rekhotov (Israel, 1960), Eero Saarinen - The Mirror Case of the Research Institute of Electronics (USA, 1961 year), Mies van der Rohe - a scientific center in Pittsburgh (USA, 1965).

Universities are becoming the link between science, research centers and industrial production. The beginning of interaction, on which the advanced economies of the world are based today, was laid in the United States in the 1950s, when the first scientific and educational center "Silicon valley" of Stanford University (California) was organized.

The San Francisco Bay area has long been a major location for the development and research of U.S. Navy structures. In 1909, the first radio station in the United States was founded in San Jose. A year later, Stanford graduate Cyril Elville acquired a patent for radio transmission technology and founded the Federal Telegraph Corporation in Palo Alto. Over the next decade, his company (FTC) created the world's first global radio network and signed a contract with the US Navy in 1912.

Until the mid-thirties of the XX century, the territory of the Valley was occupied by enterprises serving the US Navy, later a significant part of the territory was occupied by the US Air Force and NASA organizations with research in the field of aeronautics. The father of Silicon Valley is FrederickTerman, a professor at Stanford University who in 1939 convinced his students William Hewlett and David Packard to establish their own venture, leading to the birth of a giant like Hewlett-Packard With.

Hewlett-Packard became the first civilian science and technology company in the Valley. After the Second World War, the university was faced with a shortage of money, and the university management decided to receive funds for the further development of Stanford from 
3.240 hectares of free land by leasing it for a moderate fee to companies involved in new technological developments [3].

As these companies created many new jobs, the "brain drain" problem was resolved - the outflow of students who had finished Stanford to other parts of the country to work stopped. There were special financial assistance programs, every effort was made to leave young, talented researchers in California, to create the conditions for the development of their scientific research and business in the area. This marked the beginning of the formation of the Stanford Research Institute in 1946, and The Stanford Industrial Park was created in 1951 - these were, in essence, the first high-tech "incubators".

Fairchild Semiconductor Corp. was founded in Silicon Valley in 1957 and became a pioneer in silicon chip manufacturing, setting new traditions that led to the growth of the innovative economy of both Silicon Valley and the United States. Currently, there are many Fortune1000 companies located in Silicon Valley, of which $23 \mathrm{com}$ panies were founded in the Valley, including Adobe Systems, Agilent Technologies, AMD, Google, Intel, Yahoo.

The most important achievement of Silicon valley was its unique atmosphere of openness and mutual assistance, when the owners of competing companies called up and solved problems together, easily moving from one company to another, all issues were solved for informal conversations in one of the popular bars. In other words, loyalty to technological development was higher than loyalty to a particular company, nothing like this in States with a rich industrial history, such as Massachusetts, where employees worked in the same company for 2530 years in a sealed environment of corporate secrecy.

San Jose has increased its population by more than 10 times over the decades of the second half of the twentieth century. Now, together with the suburbs, it is among the ten largest cities in the United States. The state of California is the strongest economically state in the country: its GDP in 2015 amounted to 2.44 trillion dollars.

In domestic practice, this type of interaction has not received significant development. The formal division of science and education has caused significant damage to the scientific community and the authority of higher education [4].

In the mid-90s of the XX century the modern architectural and typological features of the concept "University campus"were defined. It combines different typological zones: study area, research area, area of social infrastructure structure, administrative area, residential area, research area, a recreation area. Examples of the formation of such complexes are the Massachusetts Institute of technology, Harvard University, Yale University and others $[5,6]$.

\section{MODERN STAGE OF DEVELOPMENT OF SCIENTIFIC AND EDUCATIONAL CENTERS}

The enlargement of universities, the erasing of interdisciplinary boundaries, and the complexity of scientific research have led to the formation of a new type of space - a scientific and educational center. A modern scientific and educational center is, first of all, a multifunctional structure, which includes various rooms, the combination of which "under one roof" gives a synergistic effect in the process of training and research work [7].

The principal components of the modern scientific and educational center of a new generation, or the functional groups of spaces, are:

1. Learning spaces that take into account the specifics of the educational process and technologies. In accordance with the new training paradigm, they should include:

- rooms for individual classes of students and consultations (for 1-5 people), small classrooms (up to 20 people), classrooms for seminars (up to 50 people), general transformable audiences for streaming groups (up to 80-150 people);

- computer rooms for distance learning, video bridges, etc. (up to 30 people), multifunctional transformable premises;

- $\quad$ special classrooms that are designed depending on the specifics of the educational process (language laboratories, etc.). A separate group can be allocated facilities for the individual work of teachers and professors (for 1 person) and facilities for the collective work of teachers (free planning, facilities for up to 20 people).

2. Spaces for scientific activity. This group of spaces of REC can be allocated premises that are associated with the organization of scientific and innovative activities of the center, they must take into account the specifics of the process and the necessary equipment. Typologically, these spaces can be divided into:

- $\quad$ laboratories (from 3 to 20 people);

- experimental production facilities. Their spatial characteristics, as well as their technical requirements, can vary over a wide range depending on the type of technology being designed (for example, for a nuclear center and a medical training center);

- $\quad$ rooms for special seminars and negotiations (from 5 to 20 people);

- offices of researchers, heads of areas, graduate students and doctoral students, as well as common rooms for formal and informal events.

3. Spaces for scientific and organizational activities. This functional group may include:

- halls for events (for example, the hall of the Academic Council for the defense of dissertations per 100 people); 
- Information centers for providing remote monitoring and training, local libraries and repositories.

4. Administrative premises. These are executive offices, department offices, meeting rooms, and premises for ensuring the functioning and operation of the building. A separate group is the premises for catering (restaurants, buffets, canteens, cafes with their office premises) and a group of rooms for large cultural and communication events - conference rooms (up to 300-500 people), congress halls (from 500 people). These rooms can be transformed $[8,9]$.

One example of such a center is the Skolkovo innovation city: a large innovative and educational center created in the Mozhaisk district of Moscow. Here, on the territory occupying about 600 hectares, it is planned to carry out work in the field of energy, information technology, telecommunications, biomedical and nuclear technologies.

The population settled within this center will be about 20 thousand people. Innograd is focused on the commercialization of the results of the work of scientists, the training of qualified personnel and the provision of assistance to the intersectoral interaction of science, education and business. It consists of a technopark capable of hosting at least 250 participating companies, providing about 2,000 jobs.

Five clusters are being organized within the framework of the technopark: BIOMED (development of biomedical technologies), ENERGOTECH (development of energy-efficient technologies), IT (development of strategic computer technologies and software), COSMOS (development of space technologies and telecommunications), YADERTECH (development of nuclear technologies).

Access to research equipment, a full range of consulting, legal and other services are provided, it is especially necessary for start-up companies. Since 2011, the Open Skolkovo University (OtUS) has been working [10].

\section{CONCLUSION}

An analysis of the historical process and architectural experience shows that the development of the architecture of research facilities began in the Middle Ages. Then architecture was transformed with the development of science and society, took on new forms, gradually filled with new functions and improving volumetric and spatial solutions.

World trends in the development of education and science show that the modern university has ceased to be a traditional place for transferring knowledge from teacher to student. Today it performs the function of forming intelligence in the form of knowledge, innovation, competencies, as a space of communication and joint work of researchers, specialists and students.

\section{ACKNOWLEDGEMENT}

Author thanks the Rector of the Southwest State University, Doctor of Technical Sciences Yemelyanov S.G.

\section{REFERENCES}

1. Aldoshin, S.M. (2014) Development of the material and technical base of science as a factor in increasing the effectiveness of scientific research. Bulletin of the Russian Academy of Sciences, № 10, 874 p.

2. Bernal, J.D. (1966) Twenty-Five Years Later. Science of Science, pp. 255-281.

3. Bronevitskaya, A.I. (2007) Research Institute of the period of the construction of communism. Project Russia, № 4, pp.46-48.

4. Puchkov, M.V. (2010) Architecture of university complexes. $170 \mathrm{p}$.

5. Thaïsa Way (2016) The urban university's hybrid campus, Journal of Landscape Architecture, 11:1, pp. 42-55

6. Rossi F., Goglio V. (2018) Satellite university campuses and economic development in peripheral regions, Studies in Higher Education

7. Dianova-Klokova, I.V., Metaniev, D.A. (2016) Social engineering in the architecture of science and innovation facilities. Academia. Architecture and Construction, № 2, pp. 71-78.

8. Puchkov, M.V. (2011) The principles of designing of a new generation of scientific and educational centers: the architecture of modern teaching technologies. Academia. Architecture and Construction, № 2, pp. 48-51.

9. MohdAnuar, EngkuMasturaEngku; Che Din, Nazli; Hussein, Hazreena (2017) Traffic Noise Influence on Soundscape Quality At Campus Landscape Area. Journal of Design and Built Environment, [S.I.], v. 17, n. 1. pp. 1-17.

10. Dianova-Klokova, I.V. (2012) The space of innovation - issues of architectural design. Architecture and Construction of Russia, № 6, pp.3-19.

Paper submitted: 13.08.2019.

Paper accepted: 15.11.2019.

This is an open access article distributed under the CC BY-NC-ND 4.0 terms and conditions. 